iron were unharmed by earthquake shocks which did enormous damage to other buildings. This apparent contradiction may perhaps be explained by supposing that a lightly-built structure would give to every movement, and a very massively-built structure would resist such movement; either would bear a considerable earthquake shock unharmed, but buildings of intermediate resisting power would be destroyed.

Upon the twisting motion often noticed in earthquakes, and especially referred to by Dr. Taylor as observed at Langenhoe, Peldon, Fingrinhoe, and Abberton, much difference of opinion has existed. From the time of Aristotle it has been commonly attributed to a vorticose movement of the earth's surface at the part affected. The effects produced seem at first quite to accord with this explanation, as when in Japan a chimney ten feet high, and two feet by three, is broken in two, the upper half being twisted diagonally round without other fracture or displacement; or when, at Mendoza, a church tower has its lower story uninjured, its middle story tumed through an angle of nearly $90^{\circ}$, and its highest story thrown completely over. But Mr. Mallet, who recorded similar cases in the Neapolitan earthquake of 1857 , clenied that this is in any case the correct explanation, and he believed that the twisting is best explained by resolved motions, due to the transit rectilinearly of the shock.

As regards the range of the recent earthquake very little more is known than was recorded during the first few days after the shock. The most important new fact is that mentioned by Dr. Prince of the shock being observed at Crowborough in Sussex; this proves that the Wealden area was affected, a!though the shock must have been very slight. Probably if the Palæozoic rocks were as near the surface there as was once hoped the shock would have been more distinctly felt.

There can now be little doubt that the origin of the shock was vertically under West Mersea or thereabouts, and that the wave must have travelled in all directions away from that area, but not necessarily with equal force and rapidity in all directions. The observations as to the direction of motion generally agree with this view; but in the neighbourhood of London there are some curious differences. The observations in London itself generally give an east and west direction, whereas some on the north side of London appear to point to a more north and south direction.

No observations are recorded of the connection of the earthquake wave with minor details of geological structure, such as the outcropping of certain hard or soft beds, or with lines of fault. The only instance of the latter kind known to me is at St. John's, near Greenwich, where the shock was felt very close to a fault, well cxposed in the railway cutting just west of St. John's Station. But another and perhaps better explanation is that the shock was there felt by an invalid lying quietly in bed, and very sensitive to movement.

In the map here given, an attempt has been made to mark the positions of all places at which the shock was felt, so far as can be learnt from published accounts; but in Esscx, Suffolk, and North Kent only a few of such places could be marked. By marking the outcrops of the older rocks (Carboniferous and earicr), the possible connection of these with the travel of the earthquake wave may be seen. This is made clearer by the section. The position of the Palæozoic rocks is known at Harwich and London; there is some uncertainty as to their position under Reading and Colchester, but for the purpose intended, and resard being had to the depth at which the shock must have originated (certainly far within the Palcozoic rocks), the line drawn is sufficiently near the truth. We can see how the shock can have been propagated throtigh the hard Palæozoic rocks and been felt where these are bare or thinly covcred with newar rocks, whereas through the thick and softer Sscondary and Tertiary rocks the wave might travel a shorter distance, Possibly also this section may suggest an explanation of the double shock which was sometimes recorded : the first would be that travelling quickly through the hard Palæozoic rocks, the second that propagated more slowly through the softer ovcrlying newer rocks.

W. TOPLEY

\section{VOLCANOES ON THE SHORES OF LAKE NYASSA, AFRICA}

D. LAWS, on his return to Europe from the mission station at the north end of Lake Nyassa, passed by Naples, where I had the pleasure of meeting him. Amongst other information that I gleaned was that pumice-stone is very abundant in the locality above-mentioned and on the shores of the lake, where pebbles of coal are also met with. He also informed me that many of the rocks had a striking resemblance to the volcanic tufas around Naples. Dr. Laws happened to have a specimen of pumice, which he kindly placed at my disposal.

The specimen forms about two-thirds of a flattened ellipsoidal pebble of about $\mathrm{I}_{2}^{\frac{1}{2}} \times \mathrm{I} \frac{1}{4} \times \frac{3}{4}$ inches in diameter. It is of a dirty buff colour, darker in spots, the result of oil stains in packing. The grain is fine ; there are very few large cavities, which arc multilocular, with smooth-walled spheroidal-shaped alveoli. The specific gravity of the mass is light. The characters indicate great homogeneity of material, only a moderate amount of dissolved water in the original magma, and an eruption of true paroxysmal type. A few minute crystals of sanadin are discernible with the naked eye, and rarely also a small black spot, which we shall see to be pyroxene.

It is easily scctionised, and when examined under a low power, shows a remarkable uniformity of size in the pores. Those near and opening upon the surface contain a few diatoms indicating the action of water as the cause of the pebble-like form.

The magma is a perfect glass of light straw-colour. Scattered through it are a few small irregular crystals of sanadin, fairly clear, but of irregular boundaries in many cases, as if they had wavered between crystallisation and fusion. A few are twinned on the Carlsbad type, and a few also present fine wavy striation parallel to their longer axis. At one spot were two or three sanadin crystals inclosing dark brownish-green pleochroic microliths, too irregular to measure the angle of extinction, but which looked very much like amphibole. There were to be seen a few well-formed crystals of pyroxene of light pea-green colour, quite free from pleochroism, and with characteristic crystalline boundaries and cleavage, with absence of inclosures. In the immediate neighbourhood of the large pyroxene crystals were a few microliths of the same mineral; the average angle of extinction was $49^{\circ}$, and ranging within narrow limits. No other "formed" materials were discernible exccpt a mass of dirty brown, dusty matter involved in a group of sanadin crystals, which might be magnetite. The whole character of the specimen is strikingly like some of the basic pumices of Monte Somma, and almost indistinguishable from some specimens of Phase VI. Period $\mathrm{i}$ (Quart. Fourn. Geol. Soc., January I 884).

I regret that for want of a balance I have not been able to analyse the specimen, though I am inclined to place it amongst volcanic rocks containing less than 55 per cent. of silica.

The specimen itsclf is in no way remarkable, but it is interesting as indicating the existence of continental volcanoes some hundreds of miles from the seashore, although in the immediate neighbourhood of a great lake, as also an additional grain of acquaintance with the geology of the mysterious interior of the "dark continent."

My informant has promised to forward me a collec. 
tion of rocks on his return to Lake Nyassa, which will give us a more detailed knowledge of that interesting volcanic and also coal-bearing region.

Naples, April 26

H. J. JOHNSTON-LAVIS

\section{NOTES}

Two eminent chemists died on Monday, both born in the same year-I8I7-M. Karl Adolph Wurtz and Dr. R. Angus Smith, F.R.S. M. Wurtz, who was a pall-bearer at the funeral of Dumas, is stated to have died from the bursting of a bloodvessel; he was a candidate for the vacant post of Perpetual Secretary to the Academy of Sciences. Dr. Angus Smith had been in failing health for some time. A detailed account of the careers of both chemists we must postpone till next week.

THE Council of the Royal Geographical Society have selected the following travellers for honours :-Mr. A. R. Colquhoun, for his travels in China, and Dr. Julius von Haast, for his systematic exploration of the southern island of New Zealand, the Royal Medals; Mr. W. W. M'Nair, the Murchison Grant; Mr. Emil Boss, the Bach Grant; Mr. W. O. M'Ewan, the Cuthbert Peek Grant ; and Dr. Haast, Dr. Max Buchner, and M. Ferdinand de Lesseps as honorary corresponding members.

GERMANY has been prompt in acknowledging the services of its Cholera Commission; by acclamation a bill was passed by

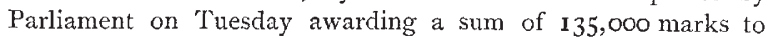
Dr. Koch and his companions.

THE Council of the British Association have resolved not to entertain any more applications for membership prior to the Montreal meeting, when members and associates will be elected as at any other meeting. The number of tickets applied for is 722 .

DURING the discussion in the Dominion House of Commons upon the vote of 25,000 dollars to defray the expenses of the meeting in Montreal in August next of the British Association, some further arrangements for the reception of members were made known. The excursion to the Rocky Mountains will, it is announced, take place on September 4, the members being taken by the New Canadian Pacific Lake route, where speciallyconstructed steamers make direct connection with the railway on each side. The excursion will probably occupy two weelss, and arrangements have been made that members of the party may not be put to greater expense than one dollar and a half per diem during the trip. Of the 25,000 dollars granted by the Dominion Parliament, 5000 will be used to defray the expenses of the mecting itself, and a fund is being raiscd to guarantee the Association against loss in connection with the publication of their proceedings. In addition to the Rocky Mountains excursion, excursions will be arranged to Ottawa, Quebec, and probably to Beloil Mountain, a locality of great geological interest. Active preparations are being made at Montreal, Toronto, and other places which will be visited, to give the members a duc reception. It has also been arranged by the Associated Atlantic Cable Company that social cable messages to and from the delegates and their friends shall be sent free of charge. This is regarded as a considerable contribution towards the success of the meeting in Montreal.

THE French Association for the Advancement of Science mcets at Blois this year from September 4 to $I \mathbf{I}$.

Prof. Huxley was examined on Tuesday before the Select Committee of the House of Commons on the Education, Science, and Art Departments. He stated that in his opinion greater attention should be paid in our public schools to physical science. The Endowed Schoois Commission was appointed to a great extent on account of the general state of apathy which existed in connection with the endowed schools. There is a distinct provision that a certain proportion of marks should be given to science and modern languages. The system, however, is not well carried out in the public schools; not more than two hours a week are given to science. There is no doubt, Prof. Huxley stated, that the Oxford and Cambridge School Examination Board Regulations tend to handicap science extremely. The examiners found their examinations on what is taught in the schools, and the schools found their instruction on the requirements of the examiners. He regarded the present system of education as wrong from top to bottom. The subjects on which most stress is laid are really luxuries, while those which are regarded as luxuries are really the most essential. The present system of education in the country shuts out young men from many employments for which they should be eligible, and tends to the employment of foreigners. Prof. Huxley thought that an influential Minister, with a seat in the Cabinet, might do a great deal to improve education. It would be his business to judge in what direction the educational system was tending, and to enforce on the educational bodies a modification of their system in the desired direction. $\mathrm{He}$ would give the Minister power to insist upon more time being given to science and modern languages.

THE Royal Society conversazione on the $7^{\text {th }}$ inst. was well attended, and the exhibits, mainly connected with physical science, interesting. Mr. J. Wimshurst exhibited the continuous electrophorus. This instrument consists of two glass disks, revolving in opposite directions upon the same axis. To the outer faces of the disks radial metallic sectors are attached, which in their turn are touched by brushes of fine wire. It is selfexciting under almost any condition of atmosphere, parts freely with its electricity, and the current will not change its direction while the instrument is at work. In Room II. was shown a map of the earthquake in Lssex (A pril 22, 1884), with photographs of damaged buildings. In Room III. Messrs. Elliott Brothers showed some electrical and magnetic apparatus, including a simplex repeater board, Wheatstone's transmitter, Wheatstone's perforator (new form), porlable electric lampss, worked by Skrivanow batteries, the Kew Committee magnetometer, and a selection of electrical and other instruments. In the principal library was a compound magnet, with bifilar suspension, showing the change in total moment produced by dividing a magnet into short lengths, exhibited by Mr. R. H. M. Bosanquet. The magnet consists of eighteen pieces of hard steel which, fitted end to end, form a cylindrical bar. These can be placed in the suspension tray either as a bar, or dispersed as separate picces. When placed together as a bar the moment is between seven and eight times as great as when the pieces are separated. The equilibrium position of the suspended tray is east and west. When a magnet is placed in the tray a deflection takes place towards north and south. The tangent of this deflection measures the moment, according to the ordinary principles of bifilar suspension. Mr. Hilger exhibitcd varions spectroscopes and a $6 \frac{1}{2}$-inch achromatic object glass in a mount of new construction. A new photometer and Dworak's sound radiometer, were sent by Mr. Preece ; and Hughes' magnetic balance, and Prof. Minchin's absolute sine electrometer, by Mr. Groves. An interesting apparatus for the generation and distribution of ozonised air, to be placed in the IIôtel-Kursaal de la Maloja, Upper Engadine, was exhibited by Dr. A. Tucker Wise. To render the air as pure as possible in this building, ozone is added to the internal atmosphere in connection with the general plan of ventilation. By means of valves this ozonised air can be turned into any room at the rate of from 60 to Ioo cubic metres per hour for each occupant. The Rev. S. J. Perry exhibited a selection from the series of drawings of the solar surface made at the Stonyhurst Observatory from I 880 to 1884 .

AT the next meeting of the Society of Telegraph Engineers and Electricians, to be held on Thursday, May 22, at the Institu- 